\title{
Quem fala no Recordações do escrivão Isaías Caminha, de Lima Barreto?
}

\author{
José Osmar de Melo \\ UNILAVRAS - UEMG
}

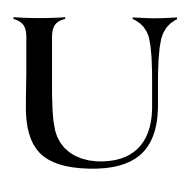

ma coisa que chama a atenção no romance Recordações do escrivão Isaías Caminha, de Lima Barreto, é o processo de despersonalização sofrido pelo personagem Isaías Caminha no decorrer da narrativa. Se, nos primeiros capítulos, a presença dele é marcantemente forte, do oitavo capítulo em diante, a sua ausência é quase total. O escritor abole a sua voz e põe em evidência a imprensa, representada pelo jornal $O$ Globo - que passa a ser o personagem que fala. De um monólogo interior, o romance se transforma em satírico-paródico, com uma escritura marcada pela violência. A denúncia da sociedade se faz presente nela, nas próprias estratégias discursivas utilizadas pelo escritor, que praticamente "mata" o narrador e a escrita à moda de fluxo de consciência, imprimindo ao Recordações, depois do oitavo capítulo, uma imprevisível escritura, caprichosa e brutal. Essa faceta marcadamente inovadora do romance, no plano estético, coloca-o na esteira do romance moderno e/ou até contemporâneo. Ou se se quiser, entre os romances que podem ser considerados, na acepção bakhtiniana, polifônicos.

E por quê? Porque o Recordações não pertence a um universo literário fechado - é aberto e polifônico. Há nele uma pluridiscursividade, na terminologia de Bakhtin. Para o autor, essa pluridiscursividade, que tem sua origem em fatores os mais diversos, manifesta-se de maneira mais clara no romance, a forma literária definida exatamente pela combinação de vozes. Nessa perspectiva, o conceito de pluridiscursividade é inseparável do conceito de dialogismo. O romance faz do dialogismo uma feição fundamental de sua composição. É importante ressaltar aqui que o conceito de dialogismo tem, ao mesmo tempo, uma dimensão sincrônica e uma dimensão diacrônica, na medida em que se revela não só nos 
aspectos miméticos do texto, isto é, no relacionamento entre o texto e o contexto sociocultural, mas também na sua intertextualidade, isto é, no seu relacionamento com outros textos passados e até futuros. Os conceitos de pluridiscursividade e dialogismo estão, por sua vez, intimamente ligados ao conceito de romance polifônico, que Bakhtin desenvolve em seu brilhante estudo sobre Dostoievsky. Ao contrário do que acontece na narrativa monológica, na narrativa polifônica, o narrador não detém autoridade absoluta em relação ao universo ficcional, pois, ao dialogar com as perspectivas dos personagens, a perspectiva do narrador tornase apenas um dos vários ângulos autônomos e de igual importância dentro do texto.

Pode-se, portanto, caracterizar Recordações do escrivão Isaías Caminha como um texto polifônico. Lima Barreto situa a ação de seu romance numa extensa área, que inclui não só a zona urbana como também as zonas suburbanas e provinciana (Isaías veio do interior). Nelas circula uma variegada galeria de personagens que vai dos mais poderosos às classes mais pobres, incluindo burocratas, políticos, um "coronel" do interior, um padre, negros, jornalistas, negociantes, profissionais liberais, prostitutas, escritores, poetas, colunistas sociais, críticos literários, deserdados, marginalizados, pobres, perseguidos, humilhados, etc. Entretanto, Lima Barreto não se limita simplesmente a registrar em seu romance a pluralidade de tipos humanos da sociedade carioca. O objetivo do autor não é apresentar suas criaturas como partes de um grande e unificado painel mas, escutando-lhes as diferentes vozes, representar a complexidade e as tensões de uma sociedade estratificada, multirracial e multicultural, em acelerado processo de transformação. Ao concretizar este projeto, o romance de Lima Barreto acaba por penetrar no âmago dos debates mais importantes para a intelectualidade brasileira da época e orquestrar a sua polifonia.

A estrutura polifônica do Recordaçôes do escrivão Isaías Caminha revela-se já no título do livro, que remete para lados diametralmente opostos. Isaías aponta para o profeta bíblico, e Caminha, para o escrivãomor da esquadra de Cabral. O próprio nome do personagem-protagonista já é portador de vozes dissonantes: uma, de denúncia; a outra, de conivência com o poder. Embora sendo portador de uma voz pendular, a posição do narrador não é de neutralidade face à realidade históricosocio-cultural brasileira. Graças à trajetória existencial de Isaías Caminha, o narrador denuncia a razão de o mulato e/ou o negro não conseguir uma 
posição que lhe é de direito na sociedade. Esta, na denúncia do narrador, é construída para e pelo branco. À voz do narrador, une-se a voz do personagem-escritor, cujo drama pode ser tomado, por exemplo, a partir das contradições presentes em sua luta, quando empregado num jornal:

Percebi que me viam como exceção; e, tendo sentido que a minha instrução era mais sólida e mais cuidada do que a maioria deles, apesar de todos os seus diplomas e títulos, fiquei animado, como ainda estou, a contradizer tão malignas e infames opiniões, seja em que terreno for, com obras sentidas e pensadas, que imagino ter força para realizá-las, não pelo talento, que julgo não ser muito grande em mim, mas pela sinceridade de minha revolta que vem bem do Amor e não do Ódio, como podem supor. ${ }^{1}$

Num processo usual dentro de suas recordações, Isaías Caminha interrompe o fluxo da narração, mediante um comentário sobre seu livro que, neste momento, está chegando ao fim. Vindo do interior para fazerse bacharel no Rio, não consegue atingir mais que a garantia da simples sobrevivência como contínuo de um jornal. Narra seu drama, descreve os mecanismos e tramóias do jornal em que trabalha, torna-se repórter protegido pelo diretor ao fim da estória. E, entremeando o texto do romance com diversas observações com acento satírico-paródico, com a finalidade de expor o mundo da imprensa, termina seu romance. Supõe que a obra dá a resposta aos bacharéis incompetentes que o julgam inferior por ser mulato e pobre. Faz isso, porém, movido por amor e não por ódio: ligado ao povo, pela origem e até mesmo pelo bairro em que mora, deveria ser possível discernir em sua denúncia a intenção de uma crítica solidária aos moradores do subúrbio.

Tal afirmativa parece ir de encontro aos eventos que compõem a história do protagonista: a solidariedade. No contexto da narração, o peso pende para o ressentimento, não para solidariedade. Morando no subúrbio, Isaías Caminha não se liga a ele: refere-se à solidariedade dos pobres, sem que dela participe, observador distante, que apenas a descreve. Essa distância de quem descreve chega a ser marcantemente exemplar em alguns trechos do romance como o já citado, em que Isaías Caminha, narrador na primeira pessoa, está lendo, num banco do passeio público e, de repente, se depara com uma rapariga negra.

${ }^{1}$ BARRETO, 1984, p. 158. 
A leitura do livro leva à percepção de que Isaías sente-se apartado de uma e de outra classe social: "Eu estava só". Face aos ricos, acha-os ridículos, revoltantes e cheios de empáfia. No que concerne aos pobres, sente comiseração deles. E lamenta a sua incompreensão diante do mulato letrado. Para os pobres, há da parte de Isaías Caminha mais pena do que solidariedade; para os ricos, revolta, ódio e ressentimento.

O ressentimento, levando Isaías Caminha à postura satírico-paródica que por vezes se detém na peroração moral, misturado ao jeitão de quem se desculpa, propondo-se a comprovar, pela sinceridade da revolta, que não é inferior como o supõem os bacharéis brancos, fariam dele um sujeito pouco simpático. Menos simpático fica, quando se sabe desde o início, pelo prefácio, que, onze anos depois:

(...) perdeu muito da sua antiga amargura, tem passeado pelo Rio com belas fatiotas, já foi ao Municipal, freqüenta casas de chá; e, segundo me escreveu, vai deixar de ser representante do Espírito Santo, na Assembléia Estadual, para ser, na próxima legislatura, deputado federal. Ele não se incomoda mais com o livro; tomou outro rumo. ${ }^{2}$

Não se importa mais com o livro: Isaías desistiu, portanto, de tentar igualar-se ou mostrar-se superior aos bacharéis, brancos e ricos, pela criação literária.Utilizou outro meio, bem mais eficaz: se os mandarins são janotas e aspiram ao poder que os representa, Isaías Caminha os igualou em seu próprio campo. Tornou-se deputado, bem vestido e, supõe-se, rico. Como se espera de qualquer branco bem sucedido. A diferença entre os dois métodos é fundamental. Isaías Caminha, diferente de ricos e pobres, brancos e negros, lhes era superior no potencial de saber literário que lhe permitiria provar a igualdade, escrevendo o seu romance. Desse modo, ele trai seu projeto de menino de província e veste a "túnica de Néssus da sociedade", esquecendo por completo os problemas denunciados no seu sincero livro de recordações que escrevera há onze anos. Ou seja, Isaías Caminha perde a própria identidade no confronto com a sociedade que sempre o recusara. Para não sucumbir e não ter um fim bastardo, assimila os seus valores, é bem sucedido, mas, por outro lado, anula-se como outro, como diferente, como mulato e como ser humano digno.

${ }^{2}$ BARRETO, 1984, p. 20. 
Segundo a Mitologia, Néssus era um centauro malicioso e traiçoeiro que tentou violar Dejanira, esposa de Hércules. Indignado, o herói o mata, mas antes de expirar, Néssus oferece a Dejanira uma túnica envenenada, dizendo que aquela indumentária teria a propriedade de garantir-lhe a fidelidade do marido. Dejanira cai na cilada vingativa do centauro e coloca sobre Hércules a túnica, a fim de tê-lo só para si. No entanto, Hércules começa a sentir dores horríveis. A túnica mortífera adere ao seu corpo de modo que para arrancá-la, é preciso arrancar junto sua própria carne. Vencido pela dor, Hércules se mata, lançando-se ao fogo. ${ }^{3}$

A "túnica de Néssus da sociedade" diz respeito, pois, à segurança enganosa do dinheiro e do status. Vestindo-a, Isaías Caminha vê-se obrigado a neutralizar a cor e a se anular como negro para ocupar e/ou conquistar o lugar que desejava: lugar esse moldado pelo e para o branco. Posteriormente, a postura satírico-paródica de Isaías Caminha em relação ao universo da classe dominante, que ele conquistou às expensas do sacrifício da compostura moral, funciona como um meio de desmascaramento da ideologia do sistema social vigente, falsamente igualitário. Lima Barreto, astuto como o Lima/autor-personagem, recorreu à Mitologia para dizer aos leitores que Isaías Caminha, vestindo a "túnica de Néssus da sociedade", se destruiria.

Sabe-se que o privilégio do saber, a se manifestar na realização literária, é padrão de valor fundamental para Lima Barreto. Em todo o conjunto de sua obra e anotações, essa idéia de realização e reconhecimento pelos outros ocorre. Como em seu projeto de escrever a História da escravidão no Brasil, sobre o qual se pode ler no Diário Íntimo: “... Mas até lá, meu Deus, que de amarguras! que de decepções! Ah! Se eu alcanço realizar essa idéia, que glória também! Enorme, extraordinária e - quem sabe uma fama européia." ${ }^{4}$

Vestir-se bem, freqüentar casas de chá, ser deputado federal, fatos identicamente abomináveis para quem escreve suas recordações amargas a respeito da diferença opressiva, são então reforço necessário para pintar o descaminho de Isaías Caminha. Ao esquecer o livro, o valor essencial da revolta foi esquecido e, portanto, ela já deixara de existir.

\footnotetext{
${ }^{3}$ SOUSA DIAS, 1994, p. 9-10.

${ }^{4}$ BARRETO, 1994, p. 64.
} 
E, todavia, ao Isaías Caminha que produz seu texto, suas recordações, acompanha o escritor Lima Barreto. Poder-se-ia até perguntar: quem é que fala nesse romance: o autor ou o narrador? Não se pode dizer, contudo, como já se comentou, que o Recordações seja um romance autobiográfico. No máximo as intrusões do autor nele quebram a homogeneidade de um mundo romanesco. E o autor surge no palco com as suas personagens: mais poderoso do que elas, ele se exime de ficar por detrás delas, deixa de esconder-se e torna-se ele próprio o centro do espetáculo.

Na primeira pessoa do singular, o EU autoral invade o romance, logo desde a "Breve Notícia":

Quando comecei a publicar na Floreal, (...) as Recordações de meu amigo, Isaías Caminha, publiquei-as com um pequeno prefácio do autor.

Eu, porém, como tinha plena autorização do autor, (...) suprimi o prefácio...

... o prefácio, penso eu, consolida a obra e a explica, como os leitores irão ver. ${ }^{5}$

Como contextualizar estes começos na primeira pessoa na voz do autor? À primeira vista, dir-se-ia que não lhe pertencem. No entanto, Lima Barreto assina a Breve Notícia que inicia o livro, à guisa de prefácio, assim como o romance, de sua autoria. Sabe-se que esse EU é um ente abstrato: não se refere nem ao autor nem ao narrador. Como pode referir-se a ambos. Sobre o EU, pesa a suspeita: não será o autor? Não será o narrador? Não será o leitor? De uma maneira geral, a narração em primeira pessoa impõe a presença maciça do autor, ainda que o narrador não se confunda com o escritor. Tente-se escrever na primeira pessoa, e compreender-seá imediatamente o que é preciso tirar a este EU para se garantir como deveras imaginário. O eu imaginário é reencontrado no ato de ler. Povoa, portanto, o espaço ficcional. Ao colocar-se nesse espaço, o autor Lima Barreto se ficcionaliza, colocando-se em pé de igualdade com o narrador e personagem do livro que escreve.

${ }^{5}$ BARRETO, 1994, p. 17. 
Há, no entanto, graus de identificação entre o autor e o narrador, como entre o leitor e o narrador. O grau mais baixo é aquele em que a personagem que conta é dotada de um nome e de uma personalidade, de uma biografia que em quase tudo se opõe à do autor. No caso do Recordaçôes do escrivão Isaías Caminha, o EU representa um grau mais próximo de identificação entre o autor e sua personagem, como se pode aferir nas seguintes falas do escrivão:

Ah! Seria doutor! Resgataria o pecado original do meu nascimento humilde, amaciaria o suplício premente, cruciante e onímodo de minha cor..."

(...) tenho os autores que mais amo. Estão ali O Crime e Castigo de Dostoievsky, um volume dos contos de Voltaire, A Guerra e Paz de Tóstoi, O Rouge et Noir de Stendhal, a Cousine Bette de Balzac, A Education Sentimentale de Flaubert, O Anté-Christ de Renan, o Eça; na estante, sob as minhas vistas, tenho o Taine, o Bouglé, o Ribot e outros autores de literatura propriamente, ou não. Confesso que os leio, que os estudo, que procuro descobrir nos grandes romancistas o segredo de fazer.'

O álcool não entrava nos meus hábitos. Em minha casa, raramente o bebia. Naquela ocasião, porém, deu-me uma vontade de beber, de me embriagar, estava cansado de sentir, queria um narcótico que fizesse descansar os nervos $(\ldots)^{8}$

Cinco capítulos da minha Clara estão na gaveta; o livro há de sair (...).

A presença do EU faz com que essas passagens soem de repente de modo pessoal. Veja-se que quem fala é Isaías Caminha, o que ressalta a identificação de Lima Barreto com sua personagem. Ao que parece, o que aproxima a voz de Isaías da de Lima Barreto é o tom revoltado e ressentido do romance. O narrador pode ser Isaías Caminha, no entanto o tom das queixas aproxima-o de Lima Barreto. Isaías, em suas semelhanças com Lima Barreto, não passa de um ser de papel. Mas

\footnotetext{
${ }^{6}$ BARRETO, 1994, p. 26.

7 BARRETO, 1994, p. 65.

${ }^{8}$ BARRETO, 1994, p. 70

${ }^{9}$ BARRETO, 1994, p. 158.
} 
também não deixa de apontar para o autor, que, vez por outra, se ficcionaliza com a persona de Isaías Caminha, para também dizer a sua verdade.

À moda de Marcel Proust em que a biografia do narrador de $\grave{A}$ la recherche du temps perdu não se confunde com a do autor, a do narrador de Recordações do escrivão Isaías Caminha não se refere a Lima Barreto. As semelhanças entre acontecimentos de pormenor não devem fazer-nos esquecer as diferenças. Os pequenos fatos isolados não chegam a constituir uma biografia, a comparação e semelhança de pequenos acontecimentos não garante a compreensão da totalidade dela como a biografia do autor. A intervenção do narrador, testemunha e ator central da intriga, explica-se por uma intervenção do autor que não é da ordem da autobiografia, nem do romance pessoal - o escrito em primeira pessoa.

A primeira pessoa, empregada por esse escritor como estratégia narrativa, permite-lhe utilizar o discurso analítico, a interpretação infinita, a leitura da essência sob as aparências, com uma liberdade que o romance na terceira pessoa não lhe teria dado: já não se sabe que é ele que fala, que descobre leis psicológicas e metáforas, essas mesmas que seriam bem difíceis para um jovem herói imaginar.

Na verdade, a enunciação invade o enunciado sem o destruir como ficção, porque é atribuído a uma mesma personagem imaginária, a qual todavia diz Eu. Escapa-se, desse modo, ao mundo do ensaio ou do romance de tese, um universo literário construído e fechado. Ao contrário, o discurso em primeira pessoa deixa o universo literário inacabado e aberto. Além disso, a primeira pessoa é proposta ao leitor enquanto um discurso já preparado, um discurso que ele seria incapaz de proferir até o momento em que o escritor lhe põe diante dos olhos um texto redigido. Por sua vez, o leitor, que se identifica - se quiser poderá evitá-lo? - com o narrador, olha, interpreta, cria, recria, constrói um outro texto, dá-lhe um novo sentido: dupla presença numa só pessoa, a primeira. A invasão maciça do autor não impede a do leitor; pelo contrário, permite-a. Tratase da enunciação invadindo, perturbando o enunciado, segundo a perspectiva de Tadié. ${ }^{10}$

O Eu presente no Recordações representa um grau mais próximo da identificação entre o autor e a sua personagem. Até certo ponto, pode-

${ }^{10}$ TADIÉ, 1992, p. 12-13. 
se dizer que a pessoa do autor e sua biografia se identificam com a vida e a trajetória de desilusões de sua personagem-protagonista, apesar de o autor tentar desfazer qualquer semelhança com o narrador ao aparecer no prefácio como o editor das recordações do seu amigo Isaías Caminha. Ao acrescentar, onze anos depois, uma outra nota a respeito de Isaías, o autor Lima Barreto, que a assina, presumivelmente se distancia ainda mais do seu personagem, no qual se podem ver muitos traços autobiográficos. Principalmente, quando acusa o seu personagem de ter vestido a "túnica de Néssus da sociedade", isto é, de ter traído seu projeto conscientizador e de compromisso com os oprimidos da sociedade. O autor se recusa a assumir, por sua própria conta, o personagem Isaías Caminha. Prefere, pois, destruí-lo. Sobra, portanto, a obra, que funciona como um elemento questionador da sociedade na qual vivia Isaías Caminha. Mas, ainda que tenha conduzido sua personagem à derrocada e este, ainda que seja um ser de papel, um ente abstrato, fictício, pura criação, não deixa de ser também máscara e rosto do autor, porque esse anti-herói (o personagem Isaías Caminha) dialoga com situações, que o leitor bem informado sabe que foram vivenciadas por seu autor Lima Barreto, a saber: a discriminação racial e social. Além disso, ao se ficcionalizar, inserindo-se na ficção - via prefácio - Lima Barreto faz o caminho inverso, como a questionar os limites entre ficção e vida.

Aliás, Bakhtin, ao estudar as relações do romancista e das suas personagens, nota que o autor devia transformar-se num outro relativamente a si próprio, ver-se com os olhos de um outro. Parece ser o que pretende Lima Barreto graças à figura de Isaías Caminha. Com efeito, se viver sob a segurança do herói, por seu intermédio, o livro fica desprovido de fundo, de profundidade, de relevo: sem forma. Numa fase intermédia, o autor domina o herói. Se este deixar de ser autobiográfico, perderá em vontade e em emoção para se subordinar a um princípio estético; se continuar a ser autobiográfico, se o autor continuar ainda a projetar-se nele, tornar-se-á "infinito" para o seu criador, exigirá sempre novas formas de acabamento: não já clássico, mas romântico. O acontecimento estético exige, para se consumar, "dois participantes, pressupõe duas consciências que não coincidem." Ou seja: uma é a do autor real, do criador de ficção, e a outra, a do narrador, do que conta a sua trajetória na narrativa. ${ }^{11}$

${ }^{11}$ BAKHTIN, 1984, p. 32-42. 
Ficcionalmente as Recordações repetem as aspirações frustradas do escritor mulato, o ressentimento e a permanente e recíproca rejeição entre ele e o meio. O olhar de Caminha, contínuo que, mais que ver e narrar, perora contra o diretor do jornal, contra os repórteres e cronistas mostrados no espaço da redação do Globo, equivale ao olhar de Lima Barreto na Secretaria da Guerra. Ter sua proposta recusada para morar numa pensão, por ser negro, como ocorre com o primeiro, é o mesmo que ser confundido com um contínuo na Secretaria, como ocorreu com Lima Barreto: fato marcante a apontar a rejeição e a alimentar o ressentimento, conforme anotado nas Recordações de um e no Diário Íntimo de outro. As frases de sentido dúbio, endereçadas ao mulato, as atitudes de rejeição, o sentimento de não estar entre os seus, seja entre os bacharéis brancos, seja entre os negros e mulatos dos subúrbios, são idênticos para o autor e para o personagem. Se o percurso de Isaías Caminha o leva a aderir ao meio que o oprime, fazendo-o perder o tom de amargura que Lima Barreto conserva até o fim, isso acontece depois de terminada a redação de seu livro. Até lá, a luta surda entre o mulato pobre e letrado e os "mandarins" é idêntica, na visão ressentida, revoltada e mesmo moralista, à do escritor.

"Quando me julgo - nada valho; quando me comparo, sou grande". A anotação de Lima Barreto, em seu diário, poderia ser a divisa de Isaías Caminha. O Rio, o jornal, os ricos, os brancos poderosos, são figuras que Barreto descreve até à náusea. Diante dos preconceitos, da dubiedade moral, dos homens poderosos que desfilam perante o mulato mal vestido sem vê-lo, apenas a constância da revolta se destaca. Isaías Caminha é olho revoltado que descreve ações que provocam o ressentimento, e é objeto dessas ações. Sua descrição e narração minuciosa e amarga superam os traços do personagem. Sua luta para subir na vida, por meio da cultura que possui mais do que os superiores, não é suficiente para destacá-lo. Mas, no cenário em que até mesmo os tiques dos figurantes repugnam, o ardor moral o torna diferente. À procura de ser igual, sendo superior.

Lima Barreto, por sua vez, se aspira à glória literária na Europa, ao iniciar definitivamente seu trabalho de escritor em 1904, carrega consigo a certeza de assim mostrar, a quem se julga mandarim das letras nacionais, a sua superioridade. Exaspera-se, portanto, com o não reconhecimento imediato dessa superioridade (que já existe sem ser reconhecida) pelo suburbano, como ele mulato e pobre: "não tem por mim nenhum respeito 
e nenhum amor, que lhe fizesse obedecer cegamente" uma vez que não reconhece "a minha superioridade." ${ }^{12}$

Isaías Caminha quer subir por opção, revolta-se pela rejeição, amargura-se pela espera. A moral branca e burguesa é arma que toma emprestada para criticar a burguesia branca: se o diretor do jornal, como quase todos os seus asseclas, é um canalha, não basta narrar-lhe as atitudes. Ele é pintado numa cena grotesca dentro de um bordel, no momento em que Caminha o procura para noticiar o suicídio do cronista social Floc:

(...) corri à sala onde estava o doutor Loberant. Estava semi-aberta. Aproximei-me da porta. A um canto havia um piano; ao centro uma mesa cheia de garrafas e copos. Pelos divãs, fumando, três pares; as mulheres em camisa e os homens também, mas mais descompostos. Em torno da mesa, uma mulher cavalgava uma espécie de tapir ou de anta. Era Aires d'Ávila, cuja peles do vasto ventre caíam como úbere de vaca. A mulher montava-o com o garbo de uma écuyère e ele rodava em torno da mesa como se fosse um animal de circo. ${ }^{13}$

A utilização da moral burguesa para a elaboração do quadro de degenerescência da burguesia, representada pela empresa jornalística, torna-se por vezes gritante. Na configuração do personagem Caminha, que se sustenta através de recusas, não é acidental nem irrelevante uma cena na qual descarta, enojado, o contato com uma prostituta velha:

Quando nos sentiu só, ela lixou-me com sua pele, encostando-se muito a mim, passando o seu braço sobre os meus ombros. Já no corredor, sob a luz de um bico de gás meio aberto, considerou bem a minha fisionomia, a minha mocidade, a falta de mulher que ela farejou logo; pegou-me carinhosamente o rosto com as duas mãos e quis beijarme...". ${ }^{14}$

Quando a população se revolta contra a lei que determina o uso obrigatório de calçados, a mesma arma chega a produzir efeitos ainda mais insólitos. A revolta popular que eclode nas ruas, dentro do quadro político

\footnotetext{
12 BARRETO, 1961, p. 76.

${ }^{13}$ BARRETO, 1994, p. 155.

${ }^{14}$ BARRETO, 1994, p. 154-155.
} 
do momento, é ambígua: instigada pelo jornal, servirá a ele para assegurarse uma influência quase sem limites sobre o governo. Mas na revolta em bruto, é o povo no meio das ruas que enfrenta corajosamente sabres e patas de cavalos, porque a cobertura dos acontecimentos pelos repórteres visa a outro fim:

Os repórteres iam aos lugares perigosos, aos pontos mais castigados pela polícia, corriam a cidade em tílburis. Nem os revisores nem os seus suplentes faltavam à chamada; outro tanto sucedia com o tipógrafos e os outros operários.Toda essa abnegação era para garantir os seus mesquinhos empregos. ${ }^{15}$

O moralismo, no entanto, não impede Isaías Caminha de aceitar os favores do patrão e o prestígio que decorre de ter sido convidado a almoçar com ele para firmar-se na redação, em tom de vingança que vence afinal (através dos bons olhos do chefe). Nem o impedirá de, em seguida, deixar o jornal em nome de uma vida simples e incorrupta no interior, decisão detonada pelo renascimento do Orgulho como resposta a um passeio com o diretor e sua amante, culminando com o momento em que Isaías Caminha descarta a expectativa dela de entrar em sua casa, sublinhada pelo cúmplice piscar de olhos do diretor. O Orgulho renasce graças à descoberta da subserviência, detonada pela recusa ao convite da mulher.

Homem de superioridade não reconhecida, mantém-se puro pela recusa do mundo, que é irremediavelmente malandro e preconceituoso. No entanto, a moral é usada no livro, uma vez que tomada de empréstimo da burguesia branca, que a profere mas não a pratica, sem o crivo da crítica. É a sua arma imediata, pouco importando que com seus dois gumes deixe, por vezes, o personagem nada bem.

Sob a arma imprópria, no entanto, reside um potencial latente. Mais que a ela, alardeia a sua cultura, o uso que dela fará, o primado das letras que chegará a ser glorioso. Esse potencial, a cultura, o cultivo das letras, alimenta também Lima Barreto.

É ele, afinal, quem pensa, no futuro, alcançar a glória e, eventualmente, a fama européia com sua História da escravidão negra. Essa História, no entanto, aparece como idéia nunca realizada e que

${ }^{15}$ BARRETO, 1994, p. 144. 
decorre em parte "do grande amor que me inspira - pudera! - a gente negra", como anotado no Diário Íntimo. Aqui duas componentes conflitantes se misturam com ingenuidade que pasma. De um lado, o sofrimento e o ressentimento. De outro, sua catarse através de uma obra literária sobre a gente negra, isto é, o oprimido, movida pelo amor. É como afirmar: o sofrimento e o ressentimento são fonte de amor, uma vez que afinal sou negro também. A elaboração da obra é fonte de realização pessoal, o que não deixa de ser ao mesmo tempo a vingança de um negro oprimido.

A complexidade da oposição não resolvida entre a singularidade do homem ressentido e a universalidade da obra sobre a multidão de oprimidos melhor se revela na aspiração a uma glória redentora (para o autor) através da fama européia. Ambos os oprimidos, autor e tema, encravados numa singularidade brasileira têm como espelho, de volta, a Europa. Ela aparece como referência e aval básico da reivindicação da individualidade e da denúncia da opressão. Seu projeto, a maneira como o descreve, o anseio e o ressentimento que o detonam e que ele deverá resolver, poderiam sem prejuízo ser trocados pelo projeto que orienta Isaías Caminha.

A isso tudo, na apresentação que redige para as Recordações, Lima Barreto antepõe um complicado mecanismo. No jogo de seus reflexos, negações e dubiedades, pode-se encontrar uma primeira manifestação da dialética do escritor Lima Barreto. As Recordações são obra do escrivão da coletoria, Isaías Caminha, preservadas e levadas à publicação por Lima Barreto, seu amigo, que a elas antepõe uma "Breve Notícia". O recurso é aparentemente cautela pessoal, ou uso literário que, se não fosse apenas ingênuo, seria ao menos de menor importância. Nisso seria semelhante a todas as afirmações que fazem uma obra pretender dizer o oposto do que realmente diz.

Lima Barreto, no entanto, não se limita a isso. Faz suceder ao seu prefácio um outro, atribuído a Isaías Caminha ele mesmo. Esse prefácio se originaria da primeira edição de seu livro, publicada através da revista Floreal que, realmente, foi editada por Lima Barreto em 1907. O jogo das datas (1916/ 1907), inclusive referências a José Veríssimo, é paralelo ao jogo de níveis autor/prefaciador/editor/personagem. No entanto, não é nesse jogo, claro e declarado de início, que irá residir o fundamental. Ele é menos a matéria que o suporte, através de um quase despistamento pela obviedade mostrada, do verdadeiro jogo de semelhanças e oposições que 
se estabelece entre o personagem e o autor. O aspecto abordado por Fantinati no livro O profeta e o escrivão, estudo sobre Lima Barreto, aproxima criador e criatura em vários aspectos. ${ }^{16}$ Chamo a atenção para o fato de que a semelhança é tão marcada que pontua o tom das afirmações de um e outro, como se pode perceber, por exemplo, quando Isaías Caminha declara não se ter escrito nos registros da livraria Garnier, nunca ter vestido casaca e, numa ironia amarga, diz-se não ser propriamente o literato, o que, junto com o resto, desculparia sua "falta de estilo e capacidade literária". ${ }^{17}$

Da mesma forma, Lima Barreto contrapõe o seu comentário:"Afora as coisas da 'Garnier', e da 'casaca' e dos 'jornais', que são preconceitos provincianos, o prefácio, penso eu, consolida a obra e a explica, como os leitores irão ver". ${ }^{18}$

A tensão entre semelhanças se exaspera: os preconceitos provincianos, levantados com ar de distante isenção crítica, são, na verdade, referência a eventos que, constantes em Lima Barreto ele mesmo, se tornam ressalva quando se referem a Isaías Caminha. Como quem, imitando quem não é, critica no semelhante uma característica sua.

A propósito dessa relação tensa entre o indivíduo, o autor e o personagem-protagonista Isaías Caminha, duas pequenas anotações dos Cahiers valéryanos podem servir para que se veja, de modo mais claro, tais oposições e semelhanças. Diz-nos a primeira:

L'individu est un dialogue. On se parle - on se voit et se juge. C'est là le grande pas mental. - Cette dualité est remarquable. Elle est plus ou moins nette. Parfois spectateur lucide et intermittent d'un trouble, d'un désespoir, d'un trans. (...) Le moi se dit moi ou toi ou il. Il y a les trois personnes en moi. La trinité. Celle qui tutoie le moi; celle qui le traite de Lui. ${ }^{19}$

Ou seja, em vez de o indivíduo ser rocha orgulhosa que atende pelo nome de eu, é uma entidade fraturada: uma permite o tuteio, a outra, distante, quase estranha, só atende pela forma cerimoniosa. O outro não

\footnotetext{
${ }^{16}$ Cf.FANTINATI, 1978.

${ }^{17}$ BARRETO, 1994, p. 20.

${ }^{18}$ BARRETO, 1994, p. 20.

19 VALÉRY, 1957, p. 440.
} 
está a priori fora do eu, inaugura-se dentro de si. E este outro interno é outro mesmo porque não é uno, mas disperso. O outro não é apenas quem empresta seu ouvido para o que diz a nossa voz. Dentro desta voz, já está o mais de um do outro. Neste sentido, as Recordaçôes do escrivão Isaías Caminha dizem de várias zonas do eu, tantas quantos são os outros que o habitam. A vivência, portanto, que essas recordações agrupam trazem à cena da ficção várias vozes, respostas várias, que, sem serem testemunhas, revelam a dimensão histórica que permeia a distância estabelecida entre a zona em que podemos ser coloquiais e aquela em que só podemos ser respeitosos em relação a nós mesmos.

A esse fragmento, pode-se juntar o segundo:

Il me semble remarquer que l'originalité du langage, le style, dépend en grande partie de l'usage que l'auteur ou l'homme fait du langage visà-vis de lui-même. ? Je ne suis pas sûr de ce que je dis là. En tout cas il est lié à l'activité mentale, et particulièrement à la sensibilité individuelle de la distance entre le langage et la pensée non verbale..$^{20}$

A partir dessa passagem, pode-se desenvolver um comentário à precedente. Os outros internos que encontro no comércio de mim para mim não são apenas imagens discrepantes de mim mesmo. Estes outros subpresentes no engendrador de recordações são transformações do nãoverbal em verbalidade. Não são apenas fantasmas de mim em mim trazidos, mas condensações do não-verbal. E, ao escreverem-se condensações do não-verbal, fala-se de tudo - paisagens, gestos, impressões, ressentimentos, revolta, denúncia, críticas ferozes contra os valores burgueses, contra a marginalização do negro, do suburbano, do deserdado. Humano e não humano, que, fazendo parte de minha ambiência, assim se transformou em marca da minha interioridade.

Daí se pode dizer que as recordações não podem nem devem se confundir com o fato histórico, mas nem por isso interessam apenas o agente individual que as compõe. Do mesmo modo, se elas se prendem às vivências do agente individual, contêm um patamar da ficcionalidade, uma via privilegiada de acesso a ela. Não sendo realidade, dizem no entanto da forma como a história foi vivida; não sendo pura ficção, dizem como em seu compositor se deposita e estrutura o ficcional. O que recorda

${ }^{20}$ VALÉRY, 1957, p. 403. 
nos permite reler o enlace entre o histórico e o ficcional, entre as facetas autobiográficas e a criação, entre o real e o não real; as recordações dizem e não dizem do autor. Velam e desvelam seu discurso polifônico e marcado pela pluralidade de vozes: do oprimido e do conivente com as estruturas sociais vigentes, do reacionário e do revolucionário. A voz de Isaías Caminha é paradoxal justamente por ser plural, polifônica, dialógica, apontando, por isso mesmo, para os vários e multifacetados discursos sociais. Na voz de Isaías Caminha, outras vozes se manifestam: a do poder e a que reivindica a mudança da sociedade. Ao conduzir seu personagem ao fracasso, o autor conclama a sociedade a lutar contra os mecanismos sociais e o poder de uma elite branca, que oprime os negros, mulatos, pobres, prostitutas, favelados, etc. Mediante a personagem Isaías Caminha, o autor parece querer passar ao leitor uma mensagem de caráter moralista: aliar-se ao poder não vale a pena. Principalmente quando se é negro ou mulato, porque a entrada nesse universo significa a perda de identidade e a identificação com os valores burgueses dos brancos.

A pretendida isenção crítica e o rápido descarte da queixa amarga, tão próprio de Lima Barreto, não só dão ao seu texto um tom que não é dele, mas são um descarte de queixas emitidas por ele mesmo. Como se, nesse momento, ele fosse o literato estabelecido e dono do julgamento marmóreo e inapelável a que aspira ser, na medida em que, pelo contrário, é ressentido e pouco conhecido.

Eis aí o primeiro produto do mecanismo montado: se o tom de Isaías Caminha não é, aí, o de Lima Barreto é como se, sob a sua assinatura, falasse um outro. Esse outro, ao surgir no prefácio do romance, é o primeiro resultado e o primeiro passo de um processo. Ver-se-á que este não se resume à produção de tais personagens paralelos ou parasitários, e que tal evento não é um evento circunstancial.

Isaías Caminha, retomando os momentos finais de seu livro, afirma:

(...) não é meu propósito também fazer uma obra de Ódio (...) mas uma defesa a acusações deduzidas superficialmente da aparência cuja essência explicadora as mais das vezes está na sociedade e não no indivíduo, desprovido de tudo, de família, de afetos, de simpatias, de fortuna, isolado contra inimigos que o odeiam, armados da velocidade da bala e da insídia do veneno. ${ }^{21}$

${ }^{21}$ BARRETO, 1994, p. 19. 
De novo, Isaías Caminha e Lima Barreto empatam. Não apenas no tom, que não é irrelevante, mas em componentes aparecem afirmações de Lima Barreto a respeito do poder redentor da obra literária para o indivíduo espezinhado. E acrescente-se aqui mais um componente que, nele, é marcante: a preocupação com o aspecto social dos dramas. Não é apenas o indivíduo que está em jogo, é a sociedade que o molda. De um lado, afirmação plenamente coerente com o Lima Barreto anarquista ou engajado. Por outro, a visão do artista, ou do homem genericamente, como produto social. Deslumbra-se o conceito de "meio", emprestado de Taine e freqüentemente retomado nos seus artigos e anotações. Conceito que, se de um lado, pode ser explicado como único instrumento a ele disponível para a socialização do seu fazer, implica, por outro, numa plena adaptação à maneira quase fatalista com que vê homem e obra: ser e evento quase passivamente condicionados pelo ambiente adverso. A idéia de ódio, marginalidade forçada, reação individualista por meio da obra literária que, mesmo imperfeita, dadas as condições do meio, redime, são perfeitamente coerentes com o conceito. Como o é, no nível individual, o ressentimento perante a adversidade: também o ressentimento é reação individual contra uma condição determinada pelo meio.

Em se tratando, porém, da relação e das oposições entre autor e personagem, pode-se verificar que, nesse jogo - que na verdade não é propriamente de máscaras, porque os disfarces são menos afivelados do que se interpenetram - conviria caracterizar melhor o pensamento de cada um. Na definição de propósitos de Isaías Caminha podem-se notar duas direções bem caracterizadas:

a) em primeiro lugar, a essência do mecanismo explica que a rejeição está na sociedade. Perante o livro, o que soar como afirmação do óbvio faz sentido: ao socializar a fonte dos preconceitos, que são a chave e a razão de ser da trama, Isaías Caminha chega realmente a explicar a obra aos leitores, como pretende Lima Barreto. Socializando, Isaías Caminha coloca em perspectiva as agruras do mulato pobre, que são espinha e carne do romance. As Recordaçôes são, de fato, a estória do aspirante desprovido de afeto, de família, de fortuna. E isso, como se sabe, tem raízes sociais. A reflexão citada faz-nos mesmo ir mais longe, e saber que o personagem também tem consciência disso.

b) No entanto, a afirmação resvala para uma ênfase que parece indicar o que nela é para seu autor o realmente importante: o fato de sentir- 
se isolado contra inimigos armados de velocidade e insídia. O universo gira de cabeça para baixo. O que era resultado de um nexo social torna-se resultado de empenho persecutório de indivíduos. E a vítima, que era vítima porque negro e pobre dentro desse nexo de marginal, porque irrelevante, torna-se subitamente figura de proa, objeto de acirrada perseguição, portanto, objeto de todas as atenções e preocupações.

Pretender-se cercado de inimigos implacáveis, que dedicam seu tempo e empenho em persegui-lo pelo fato de ser mulato e pobre, é atitude quase delirante se contraposta à constelação social que a própria frase propõe e na qual o mulato pobre é, por isso mesmo, marginal, $a$ priori.

Em suma, Isaías Caminha define um percurso peculiar até o ressentimento que já se havia encontrado no trecho final do livro, onde se propunha a escrever em nome do amor e não do ódio. O ressentimento, categoria visceralmente ligada ao âmbito individual, presa à gravitação psicológica, volta-se revoltado contra o meio. Mas o faz aspirando à lucidez, como aspira ao amor.

Nessa aspiração à lucidez, o ressentimento, num esforço sobreposto para ir mais longe, socializa-se: reconhece a origem social do que aparece como idiossincrasia. Apenas não se suporta no novo papel, que é por natureza insuportável pela contradição em termos que carrega, para então novamente mergulhar no individual e idiossincrático: socializar é provarse sem sucesso. O social passa a ser o local de inimigos solertes e insidiosos, mais sensível e muito menos claro do que o tecido da sociedade em que autor e personagem viveram.

No entanto, que validez terão estas observações, uma vez que são detonadas pelo "outro" e não pelo personagem do romance nem pelo seu autor? Isto é, nada disso faria sentido sem a isenção crítica afivelada por Lima Barreto no seu prefácio, em que censura o provincianismo e as atitudes do deputado Isaías Caminha. Do personagem, sabe-se ser em boa parte o autor (salvo no que o "outro" acrescenta à sua história). O "outro", no entanto, é criado por Lima Barreto para observar Isaías Caminha, verdadeiro personagem, portanto. Criado o "outro", no seio da ocultação e desvendamento que Lima Barreto elabora no prefácio ao seu romance, ele pretende a isenção. Ver Isaías Caminha, objetivamente, de longe. E, se Isaías Caminha é ele mesmo, ver-se objetivamente através do personagem. Aí o jogo de espelhos desmonta, por revelar-se. Na procura 
da objetividade se revela a impossibilidade de fazer do autor, do personagem e do "outro" uma só pessoa. E esse jogo impossível é o fundamento do recurso utilizado. Ao montar o "outro", Lima Barreto, que não ignora a transparência das Recordações, pretende mostrar-se vendo o personagem distante, em quase autocrítica. Dessa forma Lima Barreto ele próprio, e presente nas contradições, que não se resolvem, entre ressentimento e lucidez que aspira à socialização, torna-se muito mais claro ao assumir sua dualidade. Desdobrado, para ser visto à distância por um terceiro sem carne e sem osso, não pode, no entanto, conseguir que esse "distanciamento" seja solução. E nem parece pretendê-lo, sendo este um recurso eventual. Para que o fosse, sente-se a falta de um horizonte que, presente, tornaria possível uma síntese que, não se realizando, se protela em desdobramentos até o infinito em todas as análises que se possa efetuar à sua procura.

Acredito, no entanto, que se possa encontrar aí o mecanismo permanente da obra de Lima Barreto. Ou seja, a maneira pela qual a sua biografia, escritor mulato e pobre na Velha República, tenta se resolver no que escreveu. Claro que este primeiro exemplo escolhido facilita a tarefa. Cabe verificar a generalidade das sínteses que não se completam, fundadas na biografia e na obra. E para isso, sobretudo buscar a preponderância do ressentimento nas suas relações com o social e com o histórico; sua gênese, percurso e permanência em relação e em decorrência do horizonte disponível dentro do qual ocorrem.

A ser verdadeira a observação sobre o mecanismo encontrado no texto, o ressentimento é chave fundamental, tanto quanto possa ser em toda a sua obra e biografia, a aspiração socialista. Isso não sendo suficiente, importa saber porque no homem Lima Barreto, que é mulato, escritor e socialista, o ressentimento é preponderante e de que maneira agem e se interpenetram essas dimensões, que são biográficas, íntimas e sociais, a um dado momento da história.

Portanto, parece difícil destrinçar, separar, no Recordações, a relação narrador/autor. Embora não se possa afirmar que Isaías Caminha seja o alter ego de Lima Barreto não se pode negar que, vez por outra, Lima Barreto se identifique com a sua criatura/disfarce. Daí o que prevalece, ao que parece, é um eu que se mascara. Ora este aponta para o autor, ora para o narrador. Desse modo, Lima Barreto se ficcionaliza também no espaço da narrativa, confundindo-se com a voz ressentida e revoltada de sua criatura/disfarce, sem, contudo, assumi-la. A inclusão de uma nota no 
prefácio, onze anos mais tarde, confirma a tentativa do distanciamento. No entanto, na narrativa propriamente dita, a oscilação autor/narrador permanece. A tentativa de ludibriar o leitor no prefácio parece não ter funcionado. Se Isaías Caminha, narrador, traiu seu projeto social e redentor da mocidade, ficou o livro do autor, como um violento libelo contra uma sociedade marcadamente racista e senhorial, que até hoje insiste em empurrar para a margem, quem realmente serviu de suporte da elite branca na construção do Brasil: o negro e o mulato.

\section{Referências Bibliográficas}

\section{De Lima Barreto}

LIMA BARRETO, Afonso Henriques de. Recordações do escrivão Isaías Caminha. 3. ed., São Paulo: Ática, 1994.

LIMA BARRETO, Afonso Henriques de. Diário Íntimo. São Paulo: Brasiliense, 1961.

\section{Apoio teórico}

BAKHTIN, Mikhail. Problemas da poética de Dostoievsky. Trad. Paulo Bezerra, Rio de Janeiro: Ed. Forense-Universitária, 1981.

BAKHTIN, Mikhail. Esthétique et théorie du roman. Paris: Gallimard, 1978.

FANTINATI, Carlos Erivany. O profeta e o escrivão: estudo sobre Lima Barreto. São Paulo: ILPHA-HUCITEC, 1978.

LEJEUnE, Philippe. Le pacte autibiographique. Poétique, Paris, n.13, 1973.

MELO, José Osmar de. Quem fala no Recordaçôes do escrivão Isaías Caminha?. In: Lima Barreto e as questões de seu tempo. Belo Horizonte: Pontifícia Universidade Católica de Minas Gerais, 1997, p. 48-61. (Dissertação de Mestrado)

PROUST, Marcel. Em busca do tempo perdido. Trad. Lúcia Miguel Pereira, Porto Alegre: Globo, 1957.

TADIÉ, Jean-Yves. O romance no século XX. Trad. Miguel Serras Pereira, Lisboa: Publicações Dom Quixote, 1992. 
VALÉRY, Paul. Cahiers. Vol.I, Paris: Pléiade, 1973.

SOUSA DIAS, Carmen Lydia de. O outro trabalho de Hércules. In: LIMA BARRETO, Afonso Henriques. Recordações do escrivão Isaias Caminha. 3. ed., São Paulo: Ática, 1994.

\section{Resumo}

Recordações do escrivão Isaías Caminha, romance do escritor brasileiro Lima Barreto, é analisado sob a perspectiva do conceito bakhtiniano de dialogismo, tendo por finalidade mostrar no plano da ficção a manifestação das mais diferentes vozes sociais no seio da sociedade brasileira do fim do século XIX, como, por exemplo, a voz do negro, do pobre, dos políticos desonestos, das prostitutas, dos arrivistas, das mulheres e da imprensa corrompida, e ainda abordar pontos relativos às estratégias narrativas do texto literário, que se manifestam no complexo jogo autor/ narrador.

\section{Résumé}

Recordações do escrivão Isaías Caminha, roman de l' écrivain brésilien Lima Barreto, a été analysé sous la perspective du concept bakhtinien de dialogisme, en ayant pour but de montrer dans le plan de la fiction la manifestation de différentes voix sociales au sein de la societé brésiliènne de la fin du XIX.e siècle, comme, par exemple, la voix du nègre, du pauvre, des politiques malhonnêtes, des prostituées, des arrivistes, des femmes et de la presse corrompue, et encore d' aborder des points relatifs aux stratégies narratives du texte littéraire dans lesquelles se manifeste le complexe jeu auteur/narrateur... 